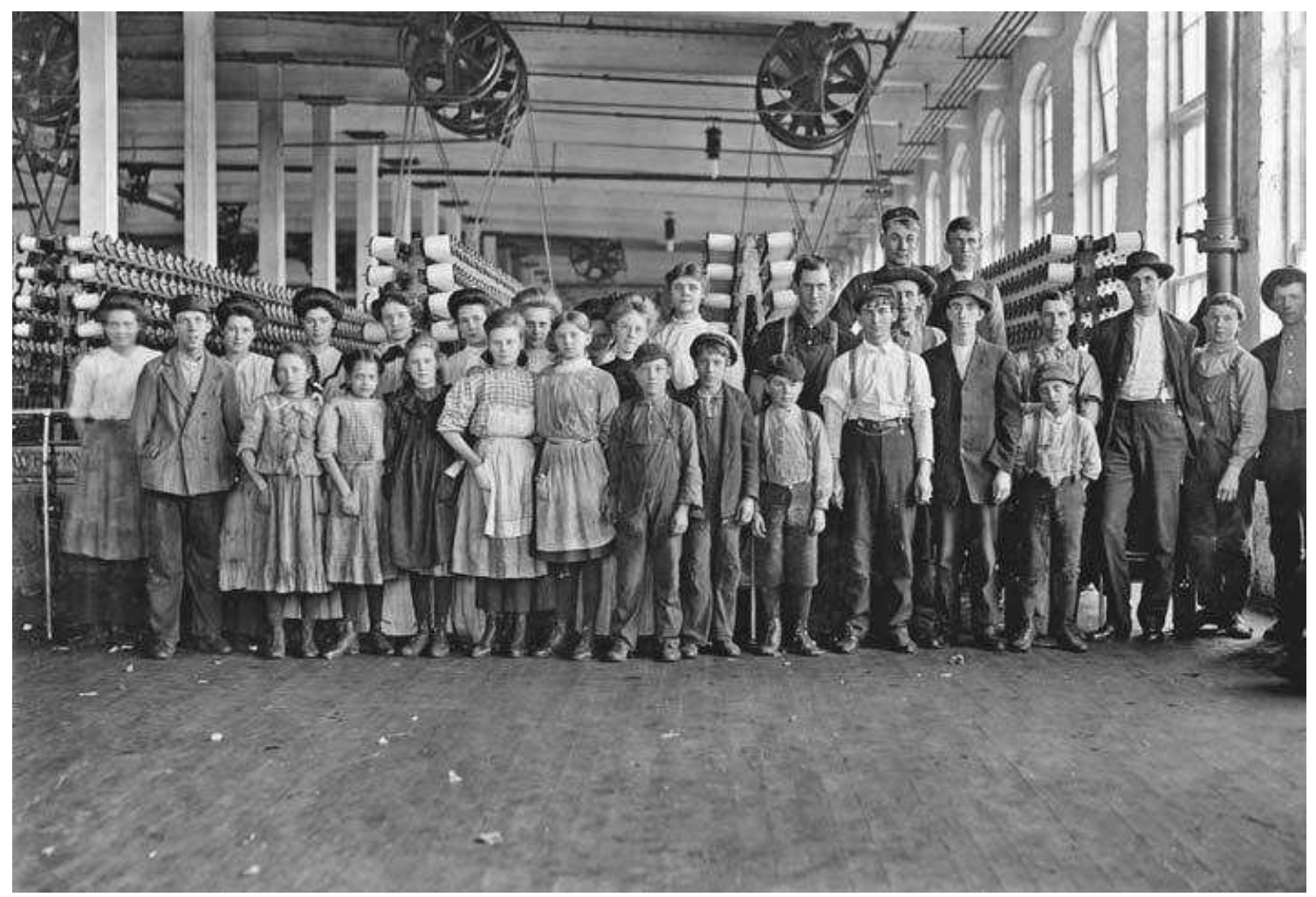

Manufatura de algodão Whitnel Co., Lewis Hine (1874-1940), NC, EUA, 1908. 


\title{
Corpo miserável, espírito empreendedor: empreendedorismo, pobreza e desemprego no Brasil
}

\author{
Miserable body, entrepreneur soul: entrepreneurship, \\ poverty and unemployment in Brazil
}

Julia Salgado*

\begin{abstract}
Resumo: Neste artigo analiso a recente figura jurídica criada pelo governo brasileiro, o Empreendedor Individual, como nova ferramenta do processo de transferência de responsabilidade pelo acesso ao mercado de trabalho - responsabilidade esta que deixa de ser coletiva, tornando-se individual. Sugiro que tal processo de transferência confere aos indivíduos a responsabilização não apenas por sua situação de desemprego, mas também de pobreza e miséria. Classificando o empreendedorismo como a melhor (ou mesmo a única) alternativa ao problema de desemprego e miséria, os discursos aqui analisados trabalham na construção de subjetividades empreendedoras como sendo positivas, requeridas e heroicas. E ao difundirem que o brasileiro é um ser "naturalmente empreendedor", naturalizam a noção de que qualquer um é capaz de sair do estado de pobreza por meio da ação empreendedora.
\end{abstract}

Palavras-chave: empreendedor individual; desemprego; subjetividade; empreendedorismo; discurso.

\begin{abstract}
In this article I analyze the recent legal figure created by the Brazilian govern, the Individual Entrepreneur, as a new tool in the process of transferring responsibility for the access in the labor market - responsibility that ceases to be collective, becoming personal. I suggest that this process of transference gives to the individuals not only the responsibility for their unemployment situation, but also of poverty and misery. Classifying the entrepreneurship as the best (or even the only) alternative to the problem of unemployment and misery, the discourses here analyzed work in the construction of entrepreneur subjectivities as being positive, required and heroic. And by disseminating that the Brazilian people are "natural entrepreneur", the notion that anyone can get out of misery by an entrepreneur action is naturalized.
\end{abstract}

Keywords: individual entrepreneur; unemployment; subjectivity; entrepreneurship; discourse.

* Jornalista, mestre em Comunicação e Cultura e doutoranda junto à Escola de Comunicação da Universidade Federal do Rio de Janeiro. Correspondência: Rua Professor Gastão Bahiana, 429/202 - Copacabana - Rio de Janeiro. CEP: 22071-030. E-mail: <juliasalgado@gmail.com>. 


\section{Introdução}

Durante uma viagem ao interior de São Paulo, por motivo de visita a familiares, deparei-me com um enorme outdoor que anunciava que aquela seria a Semana do Empreendedor Individual na pequena cidade. Ao lado de dois jovens sorridentes, e acima de uma extensa programação com palestras, cursos e cadastramentos, a chamada em letras garrafais interpelava os transeuntes: "Sou dono do meu negócio. El. Está na hora de se formalizar".

Não pude deixar de fazer uma imediata associação com um texto do economista e cientista social Jerôme Gautié. Nele, o autor francês elabora uma espécie de genealogia do conceito de desemprego, para posteriormente mostrar a sua desconstrução na sociedade contemporânea. Para mim, ficava evidente a relação entre uma "desconstrução social do desemprego" e a emergência de uma figura como a do Empreendedor Individual: se cada um dos interpelados pelo anúncio se transformasse em autônomo empreendedor, então realmente poderíamos pensar no desemprego como um conceito em vias de extinção.

Neste artigo objetivo problematizar a figura do Empreendedor Individual à luz de estudos não apenas de Gautié, mas também de autores como Michel Foucault, Alain Ehrenberg e Nikolas Rose, entre outros. Para isso, recorro à análise de discursos provenientes de materiais institucionais (tais como cartilhas e programas do governo) e de materiais midiáticos, na tentativa de perceber os processos de subjetivação em curso. Sugiro que a promoção da figura do Empreendedor Individual, ao associar o empreendedorismo a noções como desenvolvimento, prosperidade e cidadania, endossa a responsabilização individual dos sujeitos não apenas por seu estado de desemprego, mas também de pobreza e miséria.

\section{A invenção do desemprego}

Em "Da invenção do desemprego à sua desconstrução" (1998), Jerôme Gautié defende que o desemprego foi um constructo histórico, germinado no final do século XIX e consolidado nos anos 30 do século XX. É neste período que o desemprego se torna cerne da "questão social" nos países ocidentais industrializados, e objeto de intervenção pública através de políticas de pleno emprego e de assistencialismo social. A compreensão da gênese do desemprego demanda, antes, um entendimento preliminar daquilo que ele refere como "questão social":

[...] a questão social não se reduz à existência da pobreza: ela surge quando os problemas sociais são representados como tais, ou seja, quando são concebidos como remetendo à sociedade em seu conjunto, porque são causados pelo sistema social e/ou porque colocam em 
perigo esse sistema. As formulações da questão social aludem, portanto, de maneira indissociável, a representações e modalidades de ação da sociedade sobre si mesma. (GAUTIÉ, 1998, p. 69).

Gautié mostra que nas sociedades ocidentais pré-industriais (até o século XVII) o problema social residia na pobreza e na vagabundagem dos "desfiliados da tradição", fugitivos da lógica de pertencimento e serventia locais. A vagabundagem - residual até a Peste Negra, no inicio do século XIV - ganha proporções nunca antes vistas com a desordem social instaurada por esta epidemia. Do crescimento numérico, resulta a classificação dos pobres entre bons e maus: aos primeiros (inválidos, crianças e velhos) é destinada a caridade cristã, com a esmola desempenhando o papel de "serviço social local" (CASTEL apud GAUTIÉ, 1998, p. 70). Aos últimos (potencialmente válidos, porém ativamente vagabundos) cabe a repressão através das poor laws e workhouses, como já nos atentava Foucault (2008a). A distinção no tratamento entre os bons e maus pobres pode ser diretamente associada à, então em voga, ressignificação da noção de trabalho: de castigo divino e signo de falta de fortuna, o trabalho passa a ser visto como atividade honrada e indispensável para o alcance da riqueza, seja ela terrestre ou divina. Na lógica produtivista então em processo de instauração, o trabalho servirá como grande referencial para o indivíduo e sua identidade perante a sociedade.

Com a industrialização, a pobreza e a vagabundagem dos feudos locais dão lugar ao pauperismo massivo dos centros urbanos. Ao lado do miserável sem trabalho surge a figura do trabalhador miserável, que em condições sub-humanas trabalha horas a fio para ganhar menos que o necessário a uma vida decente. O pauperismo gerado pelo capitalismo industrial será, segundo Gautié, o novo problema capaz de abalar a estabilidade e a coesão social e, consequentemente, a própria ordem econômica. Mas em um contexto crescentemente influenciado pelo pensamento liberal, o direito ao trabalho não é afirmado como objeto de ação e intervenção direta do Estado; o livre acesso ao mercado de trabalho deveria ser, por si só, condição suficiente para solucionar o problema da falta de emprego. Quanto às condições de trabalho e de remuneração dos operários, o fim do século XIX marca o início da estabilização na relação trabalhador - empresa:

À concepção do direito civil, que faz do contrato de trabalho um simples contrato de troca entre dois indivíduos [...], sucederá a do direito do trabalho, que inscreve a relação de trabalho no tempo, e faz dele um vínculo de subordinação entre um indivíduo e uma entidade coletiva, a empresa. (GAUTIÉ, 1998, p. 74 - grifos no original).

Cria-se, portanto, com o vínculo de subordinação entre indivíduo e empresa, o emprego; e com ele seu negativo, o desemprego. Agora, aqueles em estado de inatividade ganham uma categoria mais ampla a qual se 
afiliar: não mais apenas vagabundos ou pobres miseráveis, mas acima de tudo desempregados. Com isto, as opções de intervenção do Estado sobre esses sujeitos se ampliam, acrescentando à repressão (aos vagabundos) e ao assistencialismo puro (aos miseráveis) a formação de corpos aptos ao tra-balho.

De fato, a busca pelo ajustamento das engrenagens do mercado de trabalho leva à criação de agências de empregos, onde poderiam ser diferidos os bons dos maus desempregados. Enquanto os primeiros se encontram nesta condição em função de um ocasional desempenho ruim da atividade econômica, devendo ser ajudados em sua recolocação no mercado; os segundos não são "material empregável", sendo, portanto, objetos de assistência (não apenas aquela financeira para a subsistência, mas também e principalmente a assistência na formação do capital humano - sempre na esperança de que o indivíduo deixe de ser um mero custo e se torne rentável). Em ambos os casos, a avaliação individual é contextualizada no cenário social e econômico em questão: "Continua-se fazendo ainda classificações de indivíduos, mas reconhece-se que a situação de alguns deles remete não a suas características próprias (defeitos ou atitudes), mas ao funcionamento do conjunto do sistema." (GAUTIÉ, 1998, p.75 - grifos no original). Encarado como problema número um da "questão social", o desemprego será, de um lado, avidamente combatido pelas políticas de pleno emprego, e de outro, amplamente atenuado em suas penúrias pelas intervenções do Welfare State.

Ao aproximar-se dos dias atuais, a análise de Gautié tenta demonstrar como o constructo desemprego, tal qual formulado no início do século passado (ou seja, como uma consequência sofrida pelo indivíduo diante de uma dada situação socioeconômica de sua sociedade), é desconstruído. Em outras palavras, o autor procura demonstrar como, agora, o desemprego passa a ser percebido como uma responsabilidade individual, e não mais social ou macroeconômica. Trata-se do

[...] retorno da localização e da individualização da intervenção pública. Esta desemboca em uma concepção em que são, antes de tudo, as características dos indivíduos que explicam sua dificuldade de inserção, e não uma disfunção do sistema econômico e social. (1998, p. 80 - grifos no original).

No âmbito deste processo, empregabilidade passa a ser conceito importante e muito usado nos anos 1990, quando o acesso ao mercado de trabalho é dificultado pela globalização e a consequente eliminação de muitos postos de trabalho. "Ter uma boa empregabilidade" deixa de ser sentença usada para referir mercados ou profissões, passando a aludir aos próprios indivíduos. Gautié conclui sugerindo que, ao redirecionar questionamentos e análises de problemas sociais a níveis individuais de resolução, "é a própria noção de 'questão social', no sentido em que definimos aqui, que perde grande parte de sua pertinência". (1998, p. 81). 
É a partir deste ponto - ou seja, de um sugerido reposicionamento do "problema desemprego", que deixa de ser coletivo e se torna individual - que gostaria de trazer algumas das reflexões de Gautié (1998) ao presente contexto brasileiro. Mais especificamente, proponho analisar a recente figura jurídica criada pelo governo brasileiro, o Empreendedor Individual, não somente como um exemplo de "desconstrução do desemprego", tal qual o movimento sugerido pelo autor. Mas também, e principalmente, como nova ferramenta do processo de transferência de responsabilidade pela inserção e permanência no mercado de trabalho, que deixa de ser uma preocupação estatal, tornando-se inexoravelmente individual. Como ferramenta, a figura do Empreendedor Individual vem acompanhada de discursos e modos de subjetivação que permitem a constituição e a legitimação de corpos adequados a esse novo modelo de governamentalidade; e que, ao incentivar indivíduos a desenvolver seu "espírito empreendedor" e abrir suas próprias empresas, elevam o empreendedorismo ao status de panaceia ao problema da pobreza e do desemprego no Brasil.

Assim sendo, proponho a análise de discursos provenientes de materiais institucionais (tais como cartilhas e programas do governo) e de materiais midiáticos, na tentativa de fazer emergir as "conexões estratégicas" (FOUCAULT, 2008a) que, em tais discursos, legitimam e naturalizam uma nova subjetividade requerida, a do indivíduo empreendedor. Sugiro que tal subjetividade condiga com um modelo de governamentalidade neoliberal, já que estimula a formação de indivíduos capazes de conduzir e gerir suas próprias vidas e trabalhos, respaldando-se cada vez menos nos mundialmente em crise programas estatais de assistencialismo (enquanto, paradoxalmente, passam a depender cada vez mais da "solidariedade" de instituições financeiras, que concedem "crédito barato" para que os empreendedores tenham capital de giro e possam investir no seu próprio negócio).

Num movimento contrário àquele descrito por Gautié (1998), quando a criação do desemprego deu margem à ampliação da intervenção do Estado sobre os indivíduos através da assistência e da formação, o atual movimento de formação de empreendedores individuais parece visar a redução - e não mais o alargamento - da atuação do Estado no mercado de trabalho. $\mathrm{E}$, ao associar o empreendedorismo à possibilidade de erradicação da miséria, tais discursos endossam a responsabilização dos indivíduos não apenas por seu estado de desemprego, mas também de pobreza e miséria.

Se a formação de corpos e mentes empreendedoras pode, portanto, ser entendida como uma tecnologia de governo que intenta, em longo prazo, mudar as configurações daquilo que entendemos como emprego (ou, ainda, relações de trabalho), a figura do Empreendedor Individual seria uma das mais recentes ferramentas de tal tecnologia. 


\section{Empreendedor Individual}

Em 1ํㅡㄹ de julho de 2009 entrou em vigor a Lei Complementar n. 128/08, que institui o Empreendedor Individual (EI) como figura jurídica pertencente a uma nova - e mais baixa - faixa de tributação do país. Pagando cerca de 37 reais ao mês (valor que atualmente corresponde a 5\% do salário mínimo vigente; mais $\mathrm{R} \$ 5,00$ de ISS destinado ao Município; mais $\mathrm{R} \$ 1,00$ de ICMS destinados ao Estado), os trabalhadores autônomos que atuam em centenas de atividades (PREVIDÊNCIA SOCIAL, 2011) ${ }^{1}$ podem formalizar seu negócio e, com isso, obter benefícios previdenciários e mercadológicos. Com o claro objetivo de trazer à legalidade (e, consequentemente, à tributação) milhões de pessoas que estão no mercado informal (PREVIDÊNCIA SOCIAL, s.d.) $)^{2}$ o El vem sendo descrito não apenas como uma inovação jurídico-tributária, mas também como um passaporte de acesso a produtos e serviços intangíveis a esse público, como concessões de crédito, cobertura previdenciária, apoio técnico e mesmo cidadania.

O Empreendedor Individual (EI) é uma inovação no sistema tributário para que milhões de brasileiros formalizem os seus negócios. [...] Os profissionais que aderirem ao El pagarão imposto 'zero' para o governo federal e terão alíquotas muito reduzidas para as demais contribuições. [...] Entre os benefícios estão: com o registro da empresa, o empreendedor passa a ter CNPJ, possibilitando a abertura de conta em banco e o acesso a crédito com juros mais baratos; cobertura da Previdência Social para o El e para a sua família; apoio técnico do Sebrae; emissão de nota fiscal para venda para outras empresas ou para o governo; dispensa da formalidade de escrituração fiscal e contábil. (SEBRAE-MT, s.d, s.p) ${ }^{3}$

A gente acredita que a lei do Empreendedor Individual traz uma revolução social para este país, porque o número de informalidade ainda é muito alto no Brasil. Hoje estima-se que são cerca de $11 \mathrm{mi}-$ Ihões de empreendedores que estão na informalidade, e para eles é interessante se formalizarem porque é um papel e ato de cidadania. Essas pessoas vão começar a ser respeitadas enquanto empreendedores e o principal: elas vão poder buscar financiamento para que seus negócios possam crescer. (ANDRADE, 2010, s.p.) ${ }^{4}$

\footnotetext{
"São cerca de 500 ocupações que podem se transformar em Empreendedores Individuais, dentre elas o ambulante, a vendedora de cosméticos, o cabeleireiro, a manicure, a esteticista, a costureira, o artesão, o fabricante de bijuterias, o borracheiro, o sapateiro, o mecânico e outros empreendedores que montam o seu próprio negócio." Guia do empreendedor individual. Disponível em: <http://www.previdencia.gov.br/arquivos/office/3_110718-161510-655.pdf>. Acesso em: 07 fev. 2012.

2 "Estudos elaborados pela PNAD 2009 apontavam que cerca de 10,8 milhões de trabalhadores por conta própria não contavam com proteção social ou proteção previdenciária. Esse é o público-alvo potencial." Disponível em: <http://www.previdencia.gov.br/conteudoDinamico.php ? $\mathrm{id}=823>$. Acesso em: 07 fev. 2012.

3 "O que é o empreendedor individual". Disponível em: <http://arquivopdf.sebrae.com.br/uf/ mato-grosso/acesse/empreendedor-individual >. Acesso em: 07 fev. 12.
} 
Com a constante e enfática menção ao benefício de acesso ao crédito, vemos que o estímulo ao empreendedorismo vai ao encontro do interesse comercial de instituições financeiras, que permanecem em sua escalada ao lucro através da venda de produtos (como financiamentos e empréstimos), que agora atinge um novo e promissor público. E com a justificativa de estimular o empreendedorismo através do microcrédito, o governo federal aprovou o subsídio ao "crédito barato" (com taxas a partir de $8 \%$ ao ano) não apenas através das agências financeiras estatais como o Banco Nacional de Desenvolvimento Econômico e Social (BNDES), Banco do Brasil ou a Caixa Econômica, mas também de bancos particulares como o Santander e o Bradesco. Ou seja, a ajuda aos pequenos empreendedores que estampa campanhas publicitárias ${ }^{5}$ e promove a empatia popular para com esses bancos é, na verdade, custeada por esse mesmo povo, através dos cofres públicos. Em um movimento já sinalizado por Bauman, de um lado ter acesso ao crédito torna-se fator de distinção social e cidadania. Do outro, governos do mundo todo (e do Brasil também) persistem na assistência aos bancos, ao que o autor chamou de "welfare para os ricos" (2011, p. 13).

O programa El, que até o início de junho de 2012 tinha dois miIhões e meio de indivíduos cadastrados, tem como meta original a formalização dos cerca de 11 milhões de brasileiros que atuam no mercado informal. Ou seja, não se trata exatamente de um projeto de geração de novos empregos, uma vez que a grande maioria dos que se formalizam já trabalha, ainda que de maneira informal. Ainda assim alguns entusiastas, como Bruno Quick, gerente de Unidade de Políticas Públicas do Serviço Brasileiro de Apoio às Micro e Pequenas Empresas (SEBRAE), fazem projeções futuras, depositando esperanças no poder de geração de empregos dos El: "Em 2015, se chegarmos a quatro milhões de empreendedores [individuais], imaginemos que um milhão deles queira aumentar seus negócios e, para isso, contrate uma pessoa a mais. Teríamos um milhão de empregos gerados por esse público". (VALOR ECONÔMICO, 2011, s.p. ${ }^{6}$

Não obstante o caráter hipotético da eficiência do programa para a geração de novos empregos, o formato desenvolvido para a figura do El tem desdobramentos que não podem ser ignorados. O primeiro, mais amplo

\footnotetext{
${ }^{4}$ Fala da gerente de Políticas Públicas do SEBRAE-MG, Nair Andrade, em entrevista ao programa Mesa de Negócios, da TV Horizonte. Disponível em: <http://www.youtube.com/ watch?v=bzxkn HENIFY\&feature=related $>$. Acesso em: 10 fev. 2012.

${ }^{5}$ "Oferecer crédito para incluir pessoas. A Santander Microcrédito oferece ao empreendedor de região de baixa renda a oportunidade de ser protagonista da mudança de sua realidade e do desenvolvimento da comunidade ao seu redor. [...] oferece empréstimos para donos de pequenos negócios (como costureiras, borracheiros, vendedores de cosméticos e pequenos comerciantes) que não têm acesso às formas convencionais de crédito." Disponível em: <http:// sustentabilidade.santander.com.br/oquefazemos/produtoseservicos/Paginas/Microcredito.aspx >. Acesso em: 01 jun. 2012.

6 VALOR ECONÓMICO. Uma revolução silenciosa feita por microempreendedores. Valor Econômico, Brasília, 22 nov. 2011. Disponível em: <http://186.208.161.138/impresso/empregoe-renda/uma-revolucao-silenciosa-feita-por-microempreendedores>. Acesso em: 02 jun. 2012.
} 
e talvez mais essencial deles, diz respeito à progressiva aculturação dos trabalhadores (sejam eles formais, informais ou mesmo desempregados) aos valores e práticas oriundos do mundo empresarial. Através de materiais didáticos, campanhas publicitárias e narrativas midiáticas o El passa a ser representado como uma "demonstração do possível" (EHRENBERG, 2010), sujeito que vem de baixo, mas que com dedicação e heroísmo supera as vicissitudes da vida e vence. Nessas narrativas, a disposição a ousar e empreender é valorada como vitória em si, numa lógica em que "perdedor" é, antes de tudo, aquele que nem ao menos tenta. Raciocínio atestado no depoimento da El Cristiane de Morais, em vídeo institucional do SEBRAEMT:

Meu marido sempre falava que queria montar um negócio de lava jato. Aí um dia eu falei: eu vou ficar aqui sentada esperando cair do céu? Eu levantei e sai, deixei meu filho com a minha mãe e fui procurar terreno. Achamos esse aqui e começamos. [...] No primeiro dia que abrimos não lavamos nenhum carro. No segundo, dois carros. No terceiro, nenhum cliente de novo. Tinha momentos em que a gente se perguntava por que a gente estava passando por aquilo [...]. No momento de tristeza, naquele momento que você pensa 'não vai dar certo', e que você quer algo, mas tem dúvida, joga a dúvida de lado! Nem que você quebre a cabeça, mas você tenta. (SEBRAE-MT, 2011, s.p.) ${ }^{7}$.

As subjetividades empreendedoras ganham, nas caracterizações dos Els, interpretações sempre positivas (energia, flexibilidade, autonomia), deixando ao campo do não dito, por exemplo, as dificuldades de ser seu próprio chefe, de fazer seus próprios horários e de não ter auxílio alheio na tomada de decisões. E assim se constrói a imagem de um individuo naturalmente satisfeito com e adequado às novas demandas do mercado de trabalho, um individuo cujo "espírito empreendedor" acompanha o "novo espírito do capitalismo" (BOLTANSKI; CHIAPELLO, 2009).

Um segundo desdobramento percebido na promoção do El é a sugestão de que esta figura, fruto de um esforço do governo em legalizar e conferir seguridade aos trabalhadores informais, pode ser alternativa viável e benéfica para a solução do Estado não só de desemprego, mas também de miséria de milhares de brasileiros. É o que mostra a análise de algumas reportagens sobre o tema. No dia 17 de novembro de 2011 o jornal Valor Econômico veiculou a reportagem "Formalização de 'bicos' ajuda a erradicar miséria, avalia governo", na qual são apresentadas as expectativas do governo sobre o programa El para os problemas do desemprego e da miséria.

O governo Dilma Rousseff espera contar com a formalização dos chamados 'bicos', pequenos serviços sem vínculos empregatícios,

\footnotetext{
7 Disponível em: <http://arquivopdf.sebrae.com.br/uf/mato-grosso/acesse/empreendedorindividual>. Acesso em: 07 fev. 12.
} 
para reduzir a miséria até 2014 a ponto de erradicá-la. O diretor de Inclusão Produtiva do Ministério do Desenvolvimento Social (MDS), Luiz Muller, afirmou hoje [...] ser preciso convencer as pessoas do 'núcleo duro da miséria' de que possuem conhecimento suficiente para entrar no mundo da formalidade. A proposta 'não é fácil', reconhece Muller, porque 'quem trabalha de manhã para comer à tarde' desconhece os benefícios da regularização. Luiz Muller acredita que muitos já são, de certa forma, empreendedores, mas a ilegalidade impede benefícios, como a assistência da Previdência Social e o acesso ao crédito. O governo fez parceria com o Sebrae para que a formalidade contemple não só a assinatura da carteira de trabalho, mas também o cadastramento dos assistidos pelos programas sociais como empreendedores individuais. Com o status de pequenos empresários, eles podem contratar até um funcionário pagando salário mínimo ou piso da categoria com menor carga tributária. (ALVES, 2011, s.p. - grifos nossos) ${ }^{8}$

No site da revista Pequenas Empresas, Grandes Negócios ganha destaque, em 1ำ de fevereiro de 2012, o evento "Encontro dos municípios com o desenvolvimento sustentável: pequenos negócios, qualidade ambiental urbana e erradicação da miséria". De acordo com a reportagem:

O encontro debaterá o desenvolvimento sustentável dos municípios a partir da inclusão produtiva urbana, de acordo com os parâmetros do Plano Brasil sem Miséria. A intenção é mostrar que o fortalecimento das micro e pequenas empresas e a formalização por meio do Empreendedor Individual, levando em conta as vocações econômicas locais, são instrumentos efetivos de combate à pobreza. Segundo o presidente da Frente Nacional de Prefeitos, João Coser, 'A ideia é que o brasileiro excluído tenha oportunidade nas micro e pequenas empresas, seja como empreendedor individual do seu pequeno negócio ou como empregado. Por isso, ele é fundamental para o desenvolvimento do país'. (AGÊNCIA SEBRAE DE NOTÍCIAS, 2012, s.p. grifos nossos) ${ }^{9}$

Diante de afirmações tão enfáticas sobre o poder do empreendedorismo na erradicação da pobreza o SEBRAE, em parceria com o Ministério do Desenvolvimento Social e Combate à Fome (MDS), lançou no começo de 2012 a cartilha 'O Empreendedor Individual e o Programa Bolsa Família - Uma Oportunidade para Crescer'. Apresentando o El como oportunidade única de crescimento e inclusão produtiva, a campanha, destinada aos beneficiários do programa Bolsa Família, busca demonstrar como essas pessoas podem, através do El, sair da condição de dependentes do governo, tornando-se "empresários".

\footnotetext{
${ }^{8}$ Disponível em: <http://publicidadevalordigital.valor.com. br/brasil/1098756/formalizacaode-bicos-ajuda-erradicar-miseria-avalia-governo>. Acesso em: 02 jun. 2012.

9 Disponível em: <http://revistapegn.globo.com/Revista/Common/0,,EMI292358-17180,00ENCONTRO+DEBATE+DESENVOLVIMENTO+SUSTENTAVEL+DOS+MUNICIPIOS.html>. Acesso em: 01 jun. 2012.
} 
O Brasil assumiu o desafio de acabar com a miséria e a inclusão produtiva é uma das formas de fazer com que isso aconteça. Empreendedorismo, emprego, ocupação e renda são formas de proporcionar condições dignas para uma grande parte da população, que não tem as condições básicas de bem estar social. [...] Para isso, o governo criou o Plano Brasil Sem Miséria, que aperfeiçoa e amplia o melhor da experiência brasileira na área social e fortalece as iniciativas empreendedoras da população por meio do Empreendedor Individual, uma forma rápida e sem custos para o brasileiro abrir um pequeno negócio, obtendo cobertura previdenciária com um pequeno pagamento mensal e assistência técnica gratuita do Sebrae. [...] O fato de se tornar Empreendedor Individual não leva à perda do benefício do Bolsa Família. [...] A preocupação maior desse programa é justamente complementar a renda dos cidadãos mais necessitados. A formalização como El não exclui o beneficiário e sim se apresenta como uma oportunidade de progredir econômica e socialmente e deixar de precisar do benefício. (SPÍNOLA, 2012, p. 4).

Vindo à frente do emprego, empreendedorismo é, na ordem do discurso, a grande panaceia ao problema de uma população desocupada e miserável, sendo até possível pensar, como sugerido anteriormente, que a figura do El contribua na desconstrução do desemprego enquanto categoria legítima. Ou seja, à medida que proliferam discursos enfatizando a possibilidade de qualquer um - mesmo um dependente de auxílio do governo tornar-se empreendedor, dissemina-se a noção de que apenas permanece sem trabalho ou renda quem quer. Foi mais ou menos esta a conclusão a que chegaram Lima e Arelaro (2008, p. 1), pesquisadores em Educação da USP, no artigo "Empreendedorismo e vulnerabilidade dos trabalhadores empobrecidos":

O resultado da análise revelou que a defesa do empreendedorismo como alternativa aos 'perdedores' da globalização mostra a intenção de propagar a mensagem que trabalhadores desempregados e informais são desajustados que precisam se ajustar, e que 'ganhadores' são empreendedores, dispostos a 'riscos financeiros, psicológicos e sociais'.

Resgatando as noções de individualidade e flexibilização contidas no conceito de empregabilidade, é possível sugerir que a disposição a empreender é novo requisito necessário àqueles em busca de emprego - prova disto são anúncios de trabalho que demandam cada vez mais indivíduos proativos, criativos e empreendedores. Fora do mercado formal, um novo jogo de deveres e responsabilidades se instaura, cabendo ao governo diminuir burocracias, minimizar custos de formalização, estimular o "crédito amigo" e oferecer formação técnico-empresarial; aos sujeitos, empreender formalmente, pagando seus impostos e, de preferência, gerando os empregos que a sociedade, conjuntamente, foi incapaz de fazer. 
A transformação dos indivíduos situados na posição mais baixa da pirâmide social em empresas não vem, porém, sem o trabalho de mutação de "corpos pessoa física" em "corpos pessoa jurídica". De fato, em todos os comunicados e materiais relativos ao El há o chamamento para que os futuros empresários aprendam o caminho das pedras que leva ao crescimento, lucro e sucesso. O SEBRAE é o fomentador oficial dos cursos, palestras e material didático que vão ensinar como abrir e manter uma microempresa funcionando. Para os Els, o SEBRAE lançou o Programa SEI,

[...] composto de soluções que tratam de temas básicos para a gestão e fortalecimento dos negócios dos novos empreendedores brasileiros. O Programa aborda sete temas. [SEI Vender, SEI Comprar, SEI Controlar meu dinheiro, SEI Empreender, SEI Unir forças para melhorar, SEI Planejar, SEl Administrar] Cada um dos temas será trabalhado em diferentes formatos para facilitar o acesso empreendedor à informação. São eles: oficina presencial, cartilha, capacitação a distância via celular (SMS) e kit educativo. (SEBRAE-RO, s.d., s.p.) ${ }^{10}$

Dedicando um total de 21 horas (três horas para cada tema), o El sai do SEBRAE com um certificado na mão - ao que parece, o suficiente para que seja qualificado como empresário. Além do SEBRAE, torna-se cada vez mais recorrente o ensino do empreendedorismo nos mais diversos níveis de estudo - do ensino fundamental ao superior - disseminando em nossa sociedade aquilo que poderia ser chamado de uma "cultura empreendedora". (SALGADO, 2011).

A este ponto, nada mais coerente que a indagação: como é embasada e justificada, discursivamente, a transformação de sujeitos miseráveis, em sua grande maioria com baixíssimo nível de escolaridade ${ }^{11}$, em empreendedores autônomos e autossuficientes? Como vem sendo possível fazer crer que todos - mesmo aqueles situados na margem mais externa daquilo que gostaríamos de poder chamar de "Estado social" (BAUMAN, 2011) - têm a capacidade de se tornar empresários? A resposta, segundo o governo, a mídia e "especialistas de plantão", provém da combinação de dois fatores distintos, mas que combinados constituem solução quase milagrosa aos problemas do desemprego e da pobreza. De um lado, a crença de que o empreendedorismo é a mais eficaz (ou mesmo a única!) arma viável de combate à falta de renda e ao pauperismo. Do outro, algo como um senso comum, cada vez mais disseminado, que todos nós, brasileiros, temos um "DNA empreendedor", um "espírito empreendedor" ou uma "vocação natural a empreender". Unidos, estes dois

\footnotetext{
10 Disponível em: <http://www.sebrae.com.br/uf/rondonia/orientacao-empresarial/sei-sebraeempreendedor-individual/>. Acesso em: 13 fev. 2012.

11 Segundo Pesquisa de Avaliação do Programa Bolsa Família, realizada pela DataUFF em março de 2008, 62,7\% dos beneficiários do Bolsa Família têm, no máximo, o ensino primário completo.
} 
atributos - eles próprios resultados de naturalizações discursivas - naturalizam a ideia de que, sendo o empreendedorismo a melhor saída da pobreza, e já que Deus (junto com a ginga, a alegria e a habilidade para o futebol) nos deu o dom de empreender, é nosso dever, como indivíduos e cidadãos, aproveitar este dom. Permanece pobre, portanto, quem despreza sua natureza empreendedora e não consegue enxergar as abundantes oportunidades de negócios de um país em crescimento econômico.

\section{Empreender é a solução}

Segundo Fernando Dolabela, criador de metodologias de ensino do empreendedorismo para todos os níveis escolares (do fundamental ao superior) e considerado um dos "papas" do empreendedorismo no Brasil, "Todos nascemos empreendedores. A espécie humana é empreendedora" (DOLABELA, 2008, p.23). Apesar disto, o autor defende que o empreendedorismo torna-se um fenômeno local e cultural à medida que o ambiente a que somos expostos pode funcionar como um motor ou um freio à subjetividade empreendedora. Se, desde crianças, somos expostos a valores e práticas empresariais, a tendência a nos tornarmos empreendedores de sucesso é muito maior. Se, ao contrário, nossa educação e nosso ambiente são incapazes de transferir os conceitos nascidos na empresa para o nosso dia a dia, seríamos fadados a conviver com aquilo que ele chama de "síndrome do empregado", um sério problema já que o mercado não é mais capaz de gerar empregos como outrora (DOLABELA, 2003). Foi através deste raciocínio que Dolabela conseguiu disseminar sua Pedagogia Empreendedora em escolas públicas e privadas no Brasil, fazendo do empreendedorismo disciplina obrigatória em colégios de muitos municípios brasileiros. Um dos argumentos que mais legitima a inclusão do empreendedorismo na grade curricular das escolas públicas é justamente seu proclamado "efeito antipobreza". "Empreendedorismo é coisa de pobre, principalmente de pobre, pois a única forma de se construir sustentabilidade e justiça social é através do empreendedorismo" (DOLABELA, 2010, s.p. - grifos nossos).

Enxergar o empreendedorismo como principal alternativa à falta de trabalho e renda não é ato que se restringe aos "gurus do pop-management" (COSTA et al, 2008), mais do que interessados em difundir suas expertises sobre o empreendedorismo. Na própria academia, lugar onde se haveria a esperança de encontrar vozes destoantes do coro mercadológico - coro este que elege o modelo capitalista como único viável à geração de riqueza e sobrevivência da sociedade - o empreendedorismo também é recorrentemente exaltado como solução ideal aos problemas da pobreza brasileira. Em artigo publicado no jornal Valor Econômico, o professor da Faculdade de Economia e Administração da USP, Paulo Feldmann, não faz meias palavras: 
Apenas para incorporar o contingente de jovens que vai entrar no mercado de trabalho nos próximos cinco anos será necessário gerar 50 milhões de novos empregos. E isso acontecerá em um momento em que a grande maioria das empresas estará preocupada em reduzir custos e eliminar mão de obra. Uma forma inteligente para se resolver esse dilema é estimular a capacidade empreendedora do brasileiro dando-lhe condições de criar e manter o seu próprio negócio, evitando que ele vá tentar se colocar como empregado nas grandes ou médias empresas. [...] Durante a campanha eleitoral a presidente Dilma Rousseff por diversas vezes externou a necessidade de se apoiar muito mais vigorosamente a micro e a pequena empresa brasileira. Ao assumir o governo tem reiterado que sua meta mais importante é extirpar a miséria em nosso país e há poucos dias reafirmou que vai criar o Ministério da Micro e da Pequena Empresa. Os dois temas estão totalmente interligados ou alguém ainda acredita que seria possível gerar empregos para todos os excluídos que queremos incorporar à nossa economia? A saída está em desenvolver o empreendedorismo. (2011, p. A12 - grifos nossos).

Velada e enterrada qualquer possibilidade de discutir caminhos alternativos à empresa capitalista, os esforços agora recaem sobre a necessidade de capilarizar até o nível mais individual os valores empresariais. $\mathrm{E}$ esta, certamente, não é uma constatação nova. Ao estudar a passagem do liberalismo para o neoliberalismo e propor o tema da governamentalidade no final da década de 1970, Michel Foucault aponta para a concorrência e não mais a livre troca de mercadorias - como princípio regulador não só do mercado, mas da sociedade.

[...] o que se procura obter não é uma sociedade submetida ao efeitomercadoria, é uma sociedade submetida à dinâmica concorrencial. Não uma sociedade de supermercado - uma sociedade empresarial. O homo oeconomicus que se quer reconstituir não é o homem da troca, não é o homem consumidor, é o homem da empresa e da produção. (FOUCAULT, 2008b, p. 201).

Alain Ehrenberg, em meados da década de 1990, já atentava para a emersão do empreendedor como figura generalizadamente celebrada na sociedade francesa pelas suas capacidades de representar "um indivíduo heroico que assume riscos, em vez de buscar se proteger deles por meio das instituições do Estado-providência; que busca agir sobre si mesmo, em vez de ser comandado por outros." (EHRENBERG, 2010, p. 25). Este heroísmo particular ao empreendedor, entretanto, difere da clássica conotação de exclusividade que o substantivo herói carrega, já que hoje todos teriam a chance de empreender e, assim, tornarem-se heróis ou, como diria o autor, uma "demonstração do possível". Neste sentido, o fim do século XX assistiria a uma disseminada inversão na tradicional fórmula de sucesso herdado, numa "genealogia ao inverso": a figura a ser destacada e valorizada 
passa a ser a "de começo", aquela que, fazendo-se a si mesmo, dispensa herança e associações grupais. O self made man norte-americano ressurge na figura do empreendedor que vem de baixo e alcança o sucesso.

Sob uma perspectiva diversa, Nikolas Rose (1998) examina essa "invenção do indivíduo" moderno-tardio a partir de técnicas e estratégias de governo não externas (política, religião, coerção), mas sim internas: a indução a determinados anseios e motivações pessoais, e a valorização de conceitos como liberdade, autonomia, escolha, autenticidade. Nessa transformação tecnológica da "conduta da conduta" (FOUCAULT, 2008b), ganharia corpo uma imagem fundamentada em modos de ser e agir baseados em valores particulares ao universo empresarial que, por essência, seria representativo da liberdade dogmática e da autonomia política que o livre mercado encarna. Ou seja, símbolos máximos de liberdade e autonomia contemporâneas seriam as empresas e os empresários. Seus valores, portanto, servem de exemplo e devem ser apropriados e adaptados à realidade e às práticas cotidianas do indivíduo comum, formando um arsenal de condutas que, supostamente, nos daria a autonomia para solucionar nossos mais incômodos problemas diários.

O papel referencial - ou, ainda, normativo - do empresário também aparece na análise de Richard Sennett (2010), à medida que o empresário apresenta extrema familiaridade com o "estado de incerteza", característica destacada pelo autor em seu exame do capitalismo flexível. As angústias e ansiedades geradas por uma realidade em contínua mudança perseguem, na esfera do trabalho, indivíduos destituídos de empregos e jogados à sorte de "projetos", curtos, intermitentes e desencaixados. A organização contínua de tais projetos numa narrativa sólida e coerente escaparia da responsabilidade das instituições (como as empresas ou os governos), cabendo ao próprio indivíduo saber geri-la. Emprestando de Shumpeter a imagem do empresário como destruidor criativo, Sennett sugere que sua intimidade com a incerteza faz dele "o Homem Comum ideal" nos dias atuais. (2010, p. 33).

A tarefa, como se percebe, é tornar todo e qualquer indivíduo um agente capaz de fazer a economia florescer através de práticas empreendedoras. Afinal, de que adiantaria uma sociedade democrática, com estabilidade econômica e liberdade de mercado sem corpos e mentes empreendedoras? O livre mercado capitalista apenas se realizaria plenamente, gerando "sustentabilidade e justiça social" como sugere Dolabela (2010, s.p.), com os esforços de "espíritos empreendedores". Mas, como terra de gente abençoada por natureza, o povo brasileiro aparentemente é abundante em tal recurso. É o que garantem especialistas, a mídia e os próprios brasileiros. E também a presidente da república, no primeiro dia de mandato, em seu discurso de posse: 
Para dar longevidade ao atual ciclo de crescimento é preciso garantir a estabilidade, especialmente a estabilidade de preços, e seguir eliminando as travas que ainda inibem o dinamismo da nossa economia, facilitando a produção e estimulando a capacidade empreendedora de nosso povo, da grande empresa até os pequenos negócios locais, do agronegócio à agricultura familiar. (ROUSSEFF, 2011, s.p.).

Na mídia abundam reportagens mencionando a "vocação empreendedora do brasileiro" como ingrediente capaz de driblar a pobreza e levar a negócios milionários. No Jornal Hoje, da Rede Globo, a série de reportagens "Nordeste" foi estreada com matéria que "destaca o espírito empreendedor do nordestino, brasileiros que souberam enxergar uma boa oportunidade e se transformaram em pequenos empresários". Mais uma vez o empreendedorismo é mais valorizado que o emprego na geração de riqueza: "a renda das famílias nordestinas aumentou 50\%. Os programas de transferência têm uma contribuição importante nesse segmento, mas o que é mais importante é a renda do trabalho, de pessoas que têm mais emprego, e principalmente são mais empreendedoras" (NORDESTE, 2011, s.p.).

Se é possível detectar traços empreendedores entre os nordestinos, o que dizer dos paulistas, nacionalmente conhecidos como trabalhadores incansáveis? "O espírito empreendedor que existe no estado de São Paulo é o que nos torna tão diferenciados", afirma Ozires Silva, criador da Embraer, em reportagem especial sobre as riquezas do estado mais próspero do Brasil, divulgada no portal G1 em 19/12/2011. Já o jornal O Estado de São Paulo traz histórias reais de empreendedores de sucesso na matéria cujo título já atesta: "Empreender está no DNA dos brasileiros".

Trabalhando há vários anos no Serviço de Apoio às Pequenas e Micro Empresas de São Paulo (Sebrae), o diretor superintendente Bruno Caetano concluiu que o brasileiro possui dois sonhos: ter uma casa própria e ser seu próprio patrão. 'Esse tipo de atividade está no nosso DNA.' E quem se deixou levar pelos 'genes' e abriu seu negócio fala das vantagens de ser empresário. [...] 'O mais gostoso de ter um negócio bem sucedido é a sensação de estar contribuindo socialmente, não só para o crescimento profissional dos funcionários, mas também das pessoas que dependem deles', afirma o empresário Raul Corrêa da Silva, da empresa de auditoria BDO RCS. 'O Brasil é um País eminentemente empreendedor, isso faz parte do espírito do nosso povo.' (OLIVETTI, 2011, s.p.)

Neste processo de naturalização da subjetividade empreendedora entre os brasileiros, o que se percebe é a diferenciação valorativa entre empreendedores e não-empreendedores. Resgatando a dicotomia apontada por Gautié (1998) entre "bons" e "maus" desempregados (ou, ainda, por Lima e Arelaro (2008) entre "ganhadores" e "perdedores" da globalização), 


\section{Revistg Q PII paUtg}

\} CORPO MISERÁVEL, ESPÍRITO EMPREENDEDOR - SALGADO, J. \}

os empreendedores são positivados como heróis capazes de fazer prosperar não somente sua vida, mas a de todos ao seu redor. O Brasil, portanto, precisaria de tantos empreendedores quanto fosse possível, já que os desafios nacionais de eliminar o desemprego e extirpar a miséria são imensos. Já aqueles não dispostos a correr os riscos financeiros, sociais e psicológicos envolvidos em qualquer empreendimento - como, por exemplo, os jovens que buscam nos concursos públicos a cada vez mais extinta estabilidade empregatícia - devem ser combatidos à exaustão. É o que defende, novamente, Fernando Dolabela, desta vez em entrevista à edição online da revista Veja:

Não há desenvolvimento sem empreendedorismo. Tudo o que não for empreendedorismo é custo. O governo só gera custos, ele não produz nada. Não que ele não deva existir, isso é indiscutível. Mas o emprego público é só custo. Já a empresa é o local onde se gera riqueza. [...] Esse é um grande mal do nosso governo: incentivar o concurso público. O país não pode encaminhar a sua nata intelectual para o serviço público inoperante. (DOLABELA, 2009, s.p.).

Não sem desânimo percebemos que, juntamente com naturalizações como a apenas analisada (a do empreendedor autônomo, sujeito dileto do sistema capitalista tardio-moderno), antigas construções subjetivas persistem no discurso midiático, como a do servidor público preguiçoso e inoperante, um desperdício de recursos materiais e intelectuais da nação. Fora da mídia, porém, resta a esperança de uma geração que ingressa no serviço público com um comprometimento maior que o financeiro - tratase do comprometimento social. 


\section{Revistg QIII PaUtg}

\} CORPO MISERÁVEL, ESPÍRITO EMPREENDEDOR - SALGADO, J. \}

\section{Referências}

AGÊNCIA SEBRAE DE NOTíCIAS. Encontro debate desenvolvimento sustentável dos municípios. Pequenas empresas \& grandes negócios, São Paulo, 01 fev. 2012. Disponível em: <http://revistapegn.globo.com/Revista/ Common/0,EMI292358-17180,00-ENCONTRO+DEBATE+ DESENVOLVI MENTO+SUSTENTAVEL+DOS+MUNICIPIOS.html>. Acesso em: 01 jun. 2012.

ALVES, M. Formalização de 'bicos' ajuda a erradicar miséria, avalia governo. Valor Econômico, Brasília, 17 nov. 2011. Disponível em: <http://publicidade valordigital.valor.com. br/brasil/1098756/formalizacao-de-bicos-ajudaerradicar-miseria-avalia-governo>. Acesso em: 02 jun. 2012.

ANDRADE, N. Micro Empreendedor Individual - Dicas: depoimento. [11 jun. 2010]. Mesa de Negócios: TV Horizonte. Entrevista concedida a Inácia Soares. Disponível em: <http://www.youtube.com/watch?v=bzxknHEN IFY\&feature=related $>$. Acesso em: 10 fev. 2012.

BAUMAN, Z. Vite che non possiamo permetterci. Roma: Editori Laterza, 2011.

BOLTANSKI, L; CHIAPELLO, E. O novo espírito do capitalismo. São Paulo: Martins Fontes, 2009.

COSTA, A. M. ; BARROS, D. F; MARTINS, P. M. Linguagem, relações de poder e o mundo do trabalho. Revista de Administração Pública. v. 42, n. 5, 2008.

DOLABELA, F. Pedagogia empreendedora. São Paulo: Editora de Cultura, 2003.

. O segredo de Luísa. Rio de Janeiro: Sextante, 2008.

Corrida por serviço público é mau negócio ao Brasil: depoimento. [02 dez. 2009]. Veja.com. Entrevista concedida a André Pontes. Disponível em: <http://veja.abril.com.br/ noticia/economia/corrida-servico-publicomau-negocio-ao-brasil>. Acesso em: 02 jun. 2012.

Todo mundo pode ser empreendedor: depoimento. [20 abr. 2010]. São Paulo: TV do Estado de São Paulo. Entrevista concedida a Leticia Bragaglia. Disponível em: <http://economia.estadao.com.br/noticias/neg\%C3\% B3cios,todo-mundo-pode-ser-empreendedor-diz-fernando-dolabela, 14561,0.htm>. Acesso em: 01 jun. 2012.

EHRENBERG, A. O culto da performance. São Paulo: Ed Idéias \& Letras, 2010.

FELDMANN, P. A pequena empresa como fonte de desenvolvimento. Valor Econômico, São Paulo, p. A12, 28 fev. 2011. 
FOUCAULT, M. Microfísica do poder. Rio de Janeiro, Ed. Graal, 2008a. . O nascimento da biopolítica. São Paulo: Martins Fontes, 2008b.

GAUTIÉ, J. Da invenção do desemprego à sua desconstrução. Revista MANA - Estudos de Antropologia Social. v. 4, n.2, out. 1998.

LIMA, A.L; ARELARO, L.R.G. Empreendedorismo e dignidade dos trabalhadores empobrecidos. Anais: V Encontro Luso-Brasileiro de Bioética. Porto, jul. 2008.

NORDESTE. Jornal Hoje. São Paulo: Rede Globo, 12 de outubro de 2011. Programa de TV.

OLIVETTI, C. Empreender está no DNA dos brasileiros. O Estado de São Paulo, São Paulo, 26 dez. 2011. Disponível em: <http://economia.estadao. com.br/noticias/economia, empreender-esta-no-dna-dos-brasileiros-,97296, 0.htm>. Acesso em: 30 mai. 2012.

PREVIDÊNCIA SOCIAL. Guia do empreendedor individual. Maio de 2011. Disponível em: <http://www.previdencia.gov.br/arquivos/office/3_110718161510-655.pdf>. Acesso em: 07 fev. 2012.

. Empreendedor individual. S.d. Disponível em: <http://www.previ dencia.gov.br/ conteudoDinamico.php?id=823>. Acesso em: 07 fev. 2012. ROSE, N. Inventing our selves. Cambridge University Press, 1998.

ROUSSEFF, D. Discurso de posse da presidência da república. Brasília, 01 jan. 2011. Disponível em: <http://www.brasil.gov.br/noticias/arquivos/2011/ 01/01/leia-integra-do-discurso-de-posse-de-dilma-rousseff-no-congresso $>$. Acesso em: 29 mai. 2012.

SALGADO, J. A cultura do empreendedorismo nos discursos sobre a juventude. XX Encontro da Compós, Porto Alegre - RS, jun. 2011.

SEBRAE-MT. O que é o empreendedor individual. SEBRAE Mato Grosso, s.d. Disponível em: <http://arquivopdf.sebrae.com.br/uf/mato-grosso/acesse/ empreendedor-individual>. Acesso em: 07 fev. 12.

. Histórias de empreendedores individuais. SEBRAE Mato Grosso, 27 set. 2011. Disponível em: <http://www.youtube.com/watch?v=yDkL3bP7MA>. Acesso em: 06 fev. 2012.

SEBRAE-RO. SEI - Sebrae para empreendedor individual. SEBRAE Rondônia, s.d. Disponível em: <http://www.sebrae.com.br/uf/rondonia/orientacaoempresarial/sei-sebrae-empreendedor-individual/>. Acesso em: 13 fev. 2012.

SENNETT, R. A corrosão do caráter. Rio de Janeiro: Record, 2010.

SPÍNOLA, A. Cartilha do empreendedor individual e o programa bolsa família: uma oportunidade para crescer. Brasília: SEBRAE, 2012. 


\section{ReVistg all paUtg}

\} CORPO MISERÁVEL, ESPÍRITO EMPREENDEDOR - SALGADO, J. \}

VALOR ECONÔMICO. Uma revolução silenciosa feita por microempree ndedores. Valor Econômico, Brasília, 22 nov. 2011. Disponível em: <http:/ /186.208.161.138/impresso/ emprego-e-renda/uma-revolucao-silenciosafeita-por-microempreendedores>. Acesso em: 02 jun. 2012.

Recebido em 10 de setembro de 2012.

Aprovado para publicação em 31 de outubro de 2012. 